\title{
The occurrence of glucosaminoglycan in the wall of Schizosaccharomyces pombe
}

\author{
J. H. Sietsma* and J. G. H. Wessels \\ Department of Plant Biology, University of Groningen, Biological Center, Kerklaan 30, NL 9751 NN Haren, \\ The Netherlands
}

(Received 24 May 1990; revised 9 July 1990; accepted 3 August 1990)

\begin{abstract}
The major part of the wall of Schizosaccharomyces pombe consists of $(1 \rightarrow 3)$ - $\alpha$-glucan and $(1 \rightarrow 3)$ - $\beta$-glucan with some $(1 \rightarrow 6)$ - $\beta$-linkages. Although in hydrolysed samples only a minute amount of glucosamine could be detected, this amino sugar may play an essential role as an integral part of a glucosaminoglycan/glucan complex. Treatment of the wall with either nitrous acid or chitinase changed the solubility properties of the $\beta$-glucan, which suggests that the glucosaminoglycan/glucan complex is essentially similar to that found in walls of other fungi. An enzyme with properties similar to that of chitin synthase of other fungi, and probably responsible for the synthesis of the glucosaminoglycan, was detected in a mixed-membrane fraction.
\end{abstract}

\section{Introduction}

Extensive microscopic studies have shown the spatial pattern of wall deposition during the cell cycle of Schizosaccharomyces pombe (Johnson, 1965; Streiblova, 1981; Mitchison \& Nurse, 1985) but knowledge about the role of various components in the final wall structure and the mechanism of cellular morphogenesis is still lacking.

The steady-state growth theory of hyphal growth in which fungal morphogenesis has been related to the formation of a chitin/ $\beta$-glucan complex in the wall (Wessels et al., 1983) has recently been extended to explain determinate growth in budding yeasts (Wessels et al., 1989). This complex has now been demonstrated to be present in the wall of several filamentous fungi and has also been suggested to exist in the lateral wall of the budding yeasts Saccharomyces cerevisiae (Mol \& Wessels, 1987) and Candida albicans (Elorza et al., 1987; Surarit $e t$ al., 1988). Species belonging to the genus Schizosaccharomyces have been claimed to be exceptional among ascomycetes because of the absence of chitin in their walls (Houwink \& Kreger, 1953; Bush et al., 1974; Manners \& Meyer, 1977; Horisberger et al., 1978; Bulawa et al., 1986).

In this study we show that a small amount of glucosamine is a genuine component of the wall of $S$. pombe and is probably present as a $(1 \rightarrow 4)-\beta$-linked

* Author for correspondence. email: sietsma@hgrrug5.bitnet. glucosaminoglycan covalently linked to $\beta$-glucan. A chitin synthase activity presumably responsible for the synthesis of this glucosaminoglycan was detected.

\section{Methods}

Preparation of cell walls. Schizosaccharomyces pombe var. pombe (CBS 356) was grown in YEPD medium ( $1 \%$ yeast extract, $2 \%$ peptone, $2 \%$ glucose; all w/v) at $30{ }^{\circ} \mathrm{C}$ on a rotary shaker ( 150 r.p.m.) and harvested in the late exponential phase. After washing in $50 \mathrm{~mm}$ sodium phosphate buffer $\mathrm{pH} 7 \cdot 0$, cells were disrupted by passing them twice through an X-press (Biotec, Sweden) at $-25^{\circ} \mathrm{C}$. Wall fragments were obtained as a pellet after centrifugation at $1000 \mathrm{~g}$ at $4{ }^{\circ} \mathrm{C}$ and washed five times with $50 \mathrm{~mm}$-sodium phosphate buffer. Between washings, ultrasonic treatments were applied for $30 \mathrm{~s}$ (Branson Ultrasonic at full power). Finally the walls were washed with water and freeze-dried. Microscopically, the walls were free of cytoplasmic contamination.

Fractionation of walls. Cell walls $(50 \mathrm{mg})$ were extracted twice with $5 \mathrm{ml} 1 \mathrm{M}-\mathrm{KOH}$ at $60^{\circ} \mathrm{C}$ under $\mathrm{N}_{2}$ for $20 \mathrm{~min}$ and the residue was washed with water and freeze-dried. The alkaline extract was acidified with glacial acetic acid to $\mathrm{pH} 5.0$ and the precipitate recovered by centrifugation, washed, and freeze-dried. Polymeric material remaining in the supernatant was precipitated with 2 vols ethanol, collected by centrifugation, washed with $66 \%(\mathrm{v} / \mathrm{v})$ ethanol, solubilized in water and freeze-dried.

Nitrous acid treatment was performed on non-extracted walls according to the method described by Mol \& Wessels (1987). Enzyme treatments were carried out on walls or wall fractions using $0.5 \mathrm{mg} \mathrm{ml}^{-1}$ chitinase (EC 3.2.1 14, Serratia marcescens) or exo-( $1 \rightarrow 3)$ - $\beta$-glucanase (EC 3.2.1.6, Sporotrichum globosum) in $50 \mathrm{~mm}$-sodium acetate buffer pH 5.8 at $35^{\circ} \mathrm{C}$ with $0.02 \%$ sodium azide added to prevent bacterial growth. After $24 \mathrm{~h}$, insoluble material was sedimented, fresh enzyme solution added, and the incubation continued for another $24 \mathrm{~h}$. 
Controls were incubated with buffer alone. Degradation by exo- $(1 \rightarrow 3)$ $\beta$-glucanase was determined by measuring the increase of reducing groups (as glucose equivalents) by the Nelson-Somogyi method (Somogyi, 1945).

Analytical procedures. For complete hydrolysis, walls or wall fractions $(50 \mathrm{mg}$ ) were first dissolved in $5 \mathrm{ml} \mathrm{90 \%} \mathrm{(v/v)} \mathrm{formic} \mathrm{acid} \mathrm{on} \mathrm{a} \mathrm{boiling}$ waterbath under $\mathrm{N}_{2}$ for $15 \mathrm{~min}$. Formic acid was then evaporated in vacuo over $\mathrm{KOH}$ and $\mathrm{P}_{2} \mathrm{O}_{5}$ and the residue dissolved in $5 \mathrm{ml} 0.25 \mathrm{M}^{-}$ $\mathrm{HCl}$. Hydrolysis was then completed in the presence of $2 \mathrm{~g}$ Dowex 50 W-X8 (200-400 mesh) in the $\mathrm{H}^{+}$-form at $100^{\circ} \mathrm{C}$ for $24 \mathrm{~h}$. The Dowex was eluted with 1 vol. water to collect neutral sugars and then with 5 vols $2 \mathrm{M}-\mathrm{HCl}$ to collect amino sugars. Eluates were taken to dryness and dissolved in water. Hexosamine was determined according to Johnson (1971), compounds containing free amino groups were estimated with the ninhydrin reagent (Spies, 1957), glucose and galactose were determined using glucose oxidase and galactose oxidase reagents (Boehringer), and total hexose was estimated with the anthrone reagent (Fairbairn, 1953). The quantitative difference between total hexose and glucose plus galactose values was taken as a measure of the amount of mannose in the samples, taking into account the different molar absorption coefficients of the anthrone colour development for the different sugars.

Thin-layer chromatography was done on cellulose with ethyl acetate/pyridine/acetic acid/water (5:5:1:3, by vol.) as solvent system. Reducing compounds were detected with the aniline phthalate reagent (Krebs et al., 1969).

Chitin synthase assay. Late exponential phase cells were harvested by centrifugation, washed, resuspended in $30 \mathrm{mM}$-Tris pH 7.5 containing 2 mM-EDTA and 2 mM-phenylmethylsulphonyl fluoride (PMSF), and frozen. Cells were broken by passing them twice through an X-press. After thawing and low-speed centrifugation $(1000 \mathrm{~g})$ the supernatant was centrifuged at $40000 \mathrm{~g}$ for $1 \mathrm{~h}$ at $4{ }^{\circ} \mathrm{C}$. The pellet (mixed-membrane fraction) was resuspended in $30 \mathrm{~mm}$-Tris $\mathrm{pH} 7.5,2 \mathrm{mM}-\mathrm{MgCl}_{2}$ at a protein concentration of $12.5 \mathrm{mg} \mathrm{ml}^{-1}$ and used immediately in the chitin synthase assay.

Chitin synthase activity was assayed in a $50 \mu 1$ standard reaction mixture containing $30 \mathrm{~mm}$-Tris pH 7.5, $5 \mathrm{mM}-\mathrm{MgCl}_{2}, 30 \mathrm{mM}-\mathrm{N}$-acetylglucosamine and $50 \mu \mathrm{g}$ protein of the mixed-membrane fraction. To activate latent chitin synthase, $0.5 \mu \mathrm{g}$ trypsin was added and after $5 \mathrm{~min}$, proteolysis was terminated by the addition of $1 \mu \mathrm{g}$ soybean trypsin inhibitor. The chitin synthase reaction was started by addition of $1 \mathrm{mM}$-UDP- $\mathrm{N}$-acetyl[ $\left.\mathrm{U}^{-14} \mathrm{C}\right] \mathrm{glucosamine}\left(6 \mathrm{~Bq} \mathrm{nmol}{ }^{-1}\right)$. After incubation at $30^{\circ} \mathrm{C}$ for $90 \mathrm{~min}$ the total reaction mixture was chromatographed on a thin-layer plate and scanned for radioactivity (Berthold Scanner, FRG) to determine the percentage of radioactivity remaining at the starting line, representing synthesized polymer.

For all experiments, the specific activity of the enzyme was calculated from the percentage of radioactivity incorporated into polymeric material and was expressed as nmol $N$-acetylglucosamine incorporated $\mathrm{min}^{-1}$ (mg protein) $)^{-1}$.

In some experiments chitinase $(2 \mu \mathrm{g})$ or Polyoxin $\mathrm{D}(0.5 \mu \mathrm{g})$ was added to the reaction mixture after proteolytic activation but before addition of the substrate. To analyse the effect of $\mathrm{Co}^{2+}$, the $\mathrm{MgCl}_{2}$ $(5 \mathrm{mM})$ in the standard reaction mixture was replaced by $5 \mathrm{mM}-\mathrm{CoCl}_{2}$.

For characterization of the synthesized product a larger reaction mixture $(250 \mu \mathrm{l})$ was placed as one line on a cellulose thin-layer plate and after chromatography the cellulose at the starting line was scraped from the plate and suspended in $2 \mathrm{ml} 100 \mathrm{~mm}$-sodium acetate buffer pH 5.8. Chitinase $\left(0.5 \mathrm{mg} \mathrm{ml}^{-1}\right)$ and $0.02 \%$ sodium azide were added and after $24 \mathrm{~h}$ at $35^{\circ} \mathrm{C}$ the insoluble material was sedimented and the supernatant freeze-dried. The dried material was dissolved in $50 \mu \mathrm{l}$ water, spotted on a thin-layer plate and chromatographed as above.
Chemicals. Trypsin and soybean trypsin inhibitor were obtained from Boehringer; PMSF, UDP-GlcNAc and GlcNAc were from Sigma; Polyoxin D was a gift from the Kaken Co. Chitinase (Serratia marcescens) was purchased from Serva; exo-( $1 \rightarrow 3)-\beta$-glucanase from Sporotrichum globosum was prepared as described previously (Sietsma \& Wessels, 1979). UDP- $N$-acetyl[U-14 C]glucosamine $(10.4 \mathrm{GBq}$ $\mathrm{mmol}^{-1}$ ) was obtained from Amersham.

\section{Results}

\section{Composition of the cell wall of $S$. pombe}

Table 1 shows the monomeric composition of the wall preparation. All analysis were done on walls hydrolysed in the presence of ion-exchanger after dissolution in formic acid. No differences were observed between the anthrone value obtained before and after hydrolysis, indicating minimal destruction. A mixture of $\alpha$-amylase and $\beta$-amylase did not release any anthrone-positive material from the cell wall preparation, showing the absence of contaminating (cytoplasmic) glycogen. It is noteworthy that glucosamine was clearly detectable in hydrolysed samples, both by the colour reagent of Johnson (1971) and by comparison with authentic glucosamine on thin-layer chromatograms after removal of most of the neutral sugars by ion-exchange chromatography. Glucosamine amounted to $0.5 \%$ of the dry weight of the complete wall and $60 \%$ of the glucosamine was present in the alkali-insoluble fraction, indicating that at least the latter could not have been derived from glycoproteins. The value for amino acids was obtained by correcting ninhydrin values for the presence of glucosamine; $33 \%$ appeared to be non-proteinaceous and alkali-insoluble.

Table 1. Cell wall composition of S. pombe

\begin{tabular}{lcc}
\hline \hline & \multicolumn{2}{c}{ Percentage of dry weight* } \\
\cline { 2 - 3 } & $\begin{array}{c}\text { Total } \\
\text { wall }\end{array}$ & $\begin{array}{c}\text { KOH-insoluble } \\
\text { fraction } \dagger\end{array}$ \\
\hline Glucose & $85 \cdot 2 \pm 0.67$ & $92 \cdot 8 \pm 0 \cdot 79(15 \cdot 0)$ \\
Mannose & $8 \cdot 0 \pm 0.06$ & 0 \\
Galactose & $2 \cdot 4 \pm 0 \cdot 02$ & 0 \\
Glucosamine & $0 \cdot 5 \pm 0.02$ & $2 \cdot 2 \pm 0.02(60 \cdot 0)$ \\
Amino acids $\ddagger$ & $2 \cdot 1 \pm 0.03$ & $5 \cdot 1 \pm 0.04(33 \cdot 3)$ \\
Total & $98 \cdot 2$ & $100 \cdot 1$ \\
\hline \hline
\end{tabular}

* The values represent the mean of three independent analyses performed in triplicate, \pm the standard deviation.

$\dagger$ This fraction represents $12.4 \%$ of the total wall on the basis of dry weight. Numbers in parenthesis represents the percentage of monomers present in the alkali-insoluble fraction.

$\ddagger$ Determined as ninhydrin-positive material with leucine as a standard followed by correction for the ninhydrin value of glucosamine. 
Table 2. Solubility of wall polymers after several consecutive treatments of isolated walls

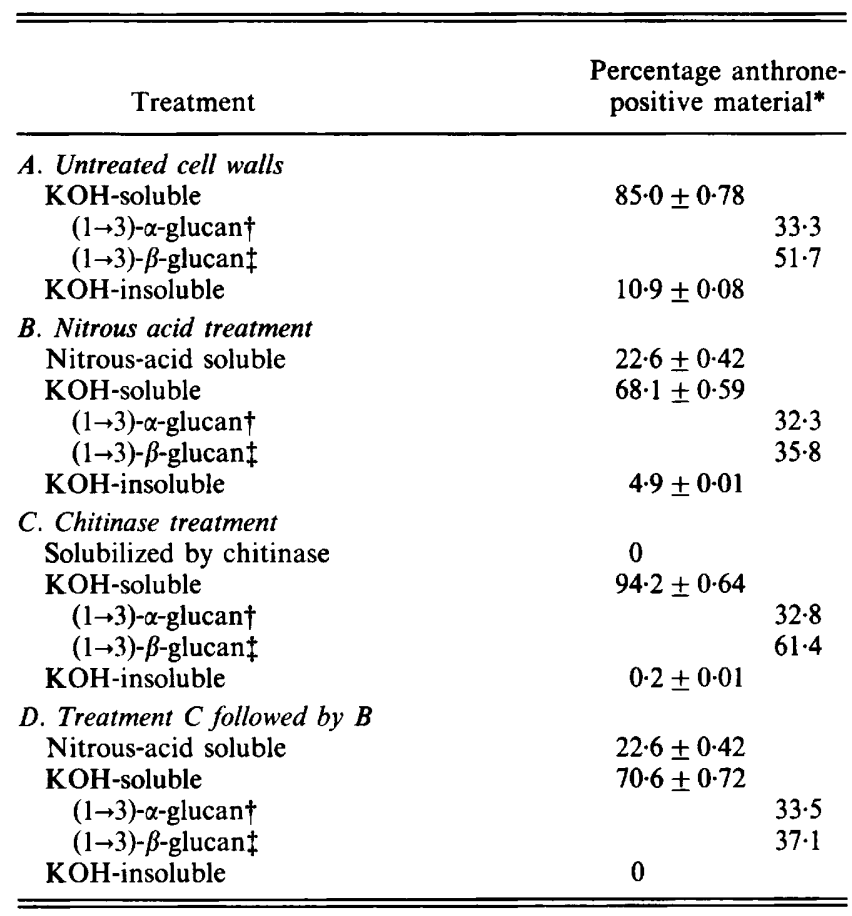

* The values represent the average of three independent analyses performed in triplicate, \pm the standard deviation.

$\dagger$ Resistant to exo- $(1 \rightarrow 3)-\beta$-glucanase.

$\ddagger$ Degraded by exo-( $(1 \rightarrow 3)$ - $\beta$-glucanase.

\section{Glucans in the wall}

According to Table 2 only $10.9 \%$ of the total anthronepositive material of the wall remained insoluble after extraction with $1 \mathrm{M}-\mathrm{KOH}$ at $60^{\circ} \mathrm{C}$ for $20 \mathrm{~min}$. This is less than the $15 \%$ of glucan remaining in this fraction (Table 1) because the mannose- and galactose-containing polymers were completely soluble in alkali. Comparing the anthrone values of alkali-extracted and alkaliinsoluble material with that of total walls it appeared that $4.1 \%$ of the anthrone-positive material was destroyed by alkali, probably because of $\beta$-elimination (Horton \& Wolfrom, 1963). When the alkaline extract was acidified with acetic acid, $44.1 \%$ of the anthrone-positive material precipitated. X-ray diffraction studies and chemical analysis have previously shown that most of this material consists of (1-3)- $\alpha$-glucan (Kreger, 1954; Bacon et al., 1968). Indeed, we found that $75.5 \%$ of this precipitated material was resistant to exo- $(1 \rightarrow 3)-\beta$-glucanase treatment $\left(48 \mathrm{~h}, 35^{\circ} \mathrm{C}\right)$. If the enzyme-resistant material is considered to be the $(1 \rightarrow 3)-\alpha$-glucan, then it amounts to $33.3 \%$ of the total anthrone-positive material. The remainder of the alkali-soluble material could be precipitated by 2 vols ethanol and was completely hydrolysed by exo-( $1 \rightarrow 3)-\beta$-glucanase. Thin-layer chromatography of the products revealed a major spot of glucose and a spot with the $R_{\mathrm{F}}$ value of gentiobiose, in addition to some minor spots with lower $R_{\mathrm{F}}$ values representing oligosaccharides (not shown). This indicates that the glucan in this fraction essentially consisted of $(1 \rightarrow 3)$ - $\beta$-glucan with a few $(1 \rightarrow 6)-\beta$-linked glucose branches attached.

\section{Glucosaminoglycan in the wall}

Table 1 shows that $0.5 \%$ of the dry weight of the wall consisted of ( $N$-acetyl)glucosamine and $60 \%$ of this material was retained in the alkali-insoluble fraction. Treatment of the wall with nitrous acid under mildly acidic conditions ( $\mathrm{pH} 3$ ) specifically destroys glycosidic linkages between amino sugars carrying a free amino group at carbon 2 (Shively \& Conrad, 1970; Stagg \& Feather, 1973). Table 2 shows that a nitrous acid treatment dissolved $22.6 \%$ of the anthrone-positive material sensitive to exo-( $1 \rightarrow 3)-\beta$-glucanase, originally belonging to both the alkali-soluble and alkali-insoluble wall fractions. No $(1 \rightarrow 3)-\alpha$-glucan was dissolved by this treatment.

Treatment of the wall with chitinase (from Serratia marcescens, free of $(1 \rightarrow 3)$ - $\beta$-glucanase) did not release any anthrone-positive material. However, after this treatment the wall almost completely dissolved in $1 \mathrm{M}-\mathrm{KOH}$ at $60{ }^{\circ} \mathrm{C}$; only $0.2 \%$ remained insoluble (Table 2 ). Treatment with chitinase and nitrous acid in succession rendered the whole wall completely soluble in water and alkali. These results indicate that the glucosaminoglycan in the wall of $S$. pombe, which is partly non-acetylated because of its sensitivity to the nitrite reagent without prior deacetylation, keeps the $\beta$-glucan in a water- and alkali-insoluble state, probably by covalent attachment.

\section{Chitin synthase activity}

After incubation of a mixed-membrane fraction of $S$. pombe with UDP-[U-14 $\mathrm{C}] \mathrm{GlcNAc}, 13 \%$ of the radioactivity was incorporated into material which remained immobile after thin-layer chromatography (Fig. 1, A). As shown in Table 3, the incorporation of radioactivity was stimulated by a short incubation $(5 \mathrm{~min})$ with trypsin; longer proteolysis caused inhibition. Substitution of $\mathrm{Co}^{2+}$ for $\mathrm{Mg}^{2+}$ gave some stimulation. Omission of the activator GlcNAc and the addition of the competitive inhibitor polyoxin $\mathrm{D}$ both decreased the activity.

For further characterization, the material remaining at the origin was scraped from the plate. The radioactive material was insoluble in water but $32 \%$ dissolved in $1 \mathrm{M}$ - 


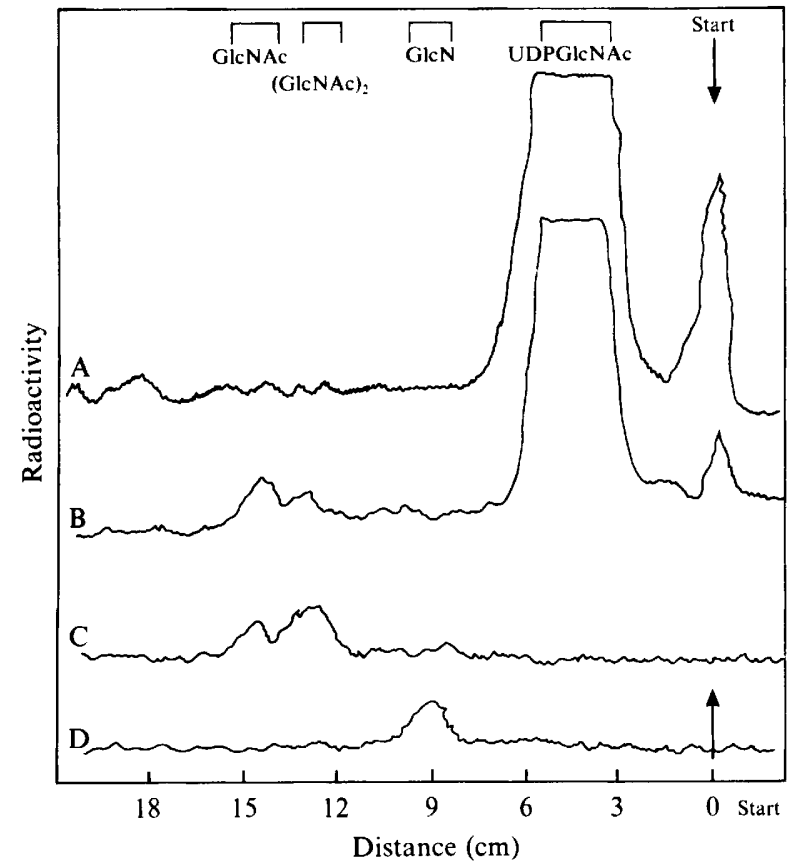

Fig. 1. Reaction products of chitin synthase activity. Distribution of the radioactivity on thin-layer plates after chromatography of: $A$, the complete reaction mixture of a mixed-membrane fraction incubated with UDP $\left[\mathrm{U}^{-14} \mathrm{C}\right] \mathrm{GlcNAc}$ under standard conditions (see Methods); $B$, the same as A, but chitinase added just before addition of the substrate; $C, D$, the material isolated from the starting line in $A$, incubated with chitinase (C) and hydrolysed with $1 \mathrm{M}-\mathrm{HCl}$. (D). GlcNAc, $N$-acetylglucosamine; (GlcNAc) $)_{2}, N$-diacetylchitobiose; GlcN, glucosamine; UDPGlcNAc, UDP- $N$-acetylglucosamine.

Table 3. Factors affecting chitin synthase activity

\begin{tabular}{lcc}
\hline \hline \multicolumn{1}{c}{ Assay mixture } & $\begin{array}{c}\text { Trypsin } \\
\text { treatment } \\
\text { (min) }\end{array}$ & $\begin{array}{c}\text { Specific activity } \\
\text { [nmol min }{ }^{-1} \\
(\mathrm{mg} \mathrm{protein})^{-1} \text { ] }\end{array}$ \\
\hline Standard assay mixture* & 0 & $13 \cdot 3$ \\
Standard assay mixture & 5 & $28 \cdot 8$ \\
Standard assay mixture & 15 & $17 \cdot 8$ \\
Standard assay mixture & 30 & $8 \cdot 9$ \\
5 mM-Co ${ }^{2+}$ replacing 5 mM-Mg ${ }^{2+}$ & 5 & $46 \cdot 7$ \\
GlcNAc omitted & 5 & $4 \cdot 4$ \\
Polyoxin D added $\left(20 \mu \mathrm{g} \mathrm{ml}^{-1}\right.$ ) & 5 & $4 \cdot 4$ \\
\hline \hline
\end{tabular}

* See Methods.

KOH. Incubation with chitinase and subsequent thinlayer chromatography showed two radioactive spots with $R_{\mathrm{F}}$ values corresponding to $\mathrm{N}$-acetylchitobiose and $\mathrm{N}$ acetylglucosamine (Fig. 1, C). When the material was hydrolysed with $1 \mathrm{M}-\mathrm{HCl}$ for $1 \mathrm{~h}$ at $100^{\circ} \mathrm{C}$ the radioactivity appeared in one spot corresponding to glucosamine (Fig. 1, D). Chitinase added during the synthase reaction resulted in only chitobiose and $N$-acetylglucosamine as major reaction products (Fig. 1, B).

\section{Discussion}

Chitin is generally considered to be absent from the cell walls of S. pombe (Houwink \& Kreger, 1953; Bush et al., 1974; Manners \& Meyer, 1977; Horisberger et al., 1978; Bulawa et al., 1986). The estimated amount of amino sugars detected in $S$. pombe walls varied from less than $1 \%$ (Horisberger et al., 1978) to up to $8 \%$ (Poole \& Lloyd, 1973) of the dry weight and was not considered to be of 'chitinous' nature, but part of a surface-localized galactomannan-protein (Horisberger et al., 1978). The present study suggests that the larger part of the glucosamine is present in glucosaminoglycan, most of which is insoluble in alkali. Although part of the glucosamine in the alkalisoluble fraction of the wall may be present in $N$ glycosylated proteins, another part resides in an alkalisoluble glucosaminoglycan containing non-acetylated residues, because it is subject to depolymerization by nitrous acid. Although depolymerization was not directly established it was inferred from the fact that nitrous acid rendered a large part of the $(1 \rightarrow 3)-\beta$-glucan contained in the alkali-soluble fraction soluble at $\mathrm{pH} 3$ (the $\mathrm{pH}$ at which the nitrous acid treatment was done). None of the $(1 \rightarrow 3)-\alpha$-glucan was solubilized by this treatment. We interpret this as showing that this $(1 \rightarrow 3)-\beta$-glucan fraction was immobilized in the wall by covalent linkage to a glucosamine-containing glucosaminoglycan, this complex being alkali-soluble but insoluble in water. The larger part of the glucosamine, however, is contained in the alkali-insoluble part of the wall, which further mainly consisted of $\beta$-glucan and some amino acids. Here, too, nitrous acid was effective in solubilizing a large proportion of this glucan but the most dramatic effect was caused by a chitinase treatment which, when applied to whole walls, reduced the amount of alkali-insoluble glucan to very low levels. A chitinase treatment followed by a nitrous acid treatment rendered all of the glucan in the wall soluble in water and alkali.

The presence of glucosaminoglycan in the wall of $S$. pombe was further substantiated by showing that this organism does contain a chitin synthase, contrary to a previous assumption (Bulawa et al., 1986). This chitin synthase possibly corresponds to chitin synthase 2 of Saccharomyces cerevisiae (Sburlati \& Cabib, 1986) because of its stimulation by $\mathrm{Co}^{2+}$. In $S$. cerevisiae, chitin synthase 2 represents only $5 \%$ of the total activity present. In Schizosaccharomyces pombe the chitin synthase activity per $\mathrm{mg}$ protein in the membrane fraction is roughly $3 \%$ of the total activity measured in Saccharomyces cerevisiae (not shown). We assume that the nonacetylated residues in the glucosaminoglycan arose by a deacetylation reaction (Davis \& Bartnicki-Garcia, 1984).

The presence of chitin in the wall of budding yeasts such as Saccharomyces cerevisiae is well established 
(Kreger, 1954; Bacon et al., 1966) but up to $90 \%$ occurs in the septa that separate mother and daughter cells (Bacon et al., 1966; Molano et al., 1980). The occurrence of a small amount of glucosaminoglycan in the lateral wall of $S$. cerevisiae has been inferred from autoradiography after incorporation of $\mathrm{N}$-acetylglucosamine (Molano et al., 1980), binding of wheatgerm agglutinin to the sectioned wall (Horisberger \& Rouet-Vauthey, 1985) and the solubilization of the wall after treatment with chitinase and nitrous acid (Mol \& Wessels, 1987). Notwithstanding its presumed structural role (Mol \& Wessels, 1987), the percentage of glucosaminoglycan in the lateral wall of $S$. cerevisiae would not exceed $0.3 \%$ (Molano et al., 1980). If we consider that the septum of Schizosaccharomyces pombe does contain little if any chitin, as suggested by Horisberger et al. (1978), the two yeasts would appear to be quite similar with respect to their contents of structural glucosaminoglycan ('chitin') in their walls.

\section{References}

Bacon, J. S. D., Davidson, E. D., Jones, D. \& TAYloR, I. F. (1966). The location of chitin in the yeast cell wall. Biochemical Journal 101, $36 \mathrm{C}-38 \mathrm{C}$.

Bacon, J. S. D., Jones, D., Farmer, V. C. \& Webley, D. M. (1968). The occurrence of $\alpha-(1 \rightarrow 3)$ glucan in Cryptococcus, Schizosaccharomyces and Polyporus species and its hydrolysis by a streptomycete culture filtrate lysing cell walls of Cryptococcus. Biochimica et Biophysica Acta 158, 313-315.

Bulawa, C. E., Slater M., Cabib, E., Au-Young, J., Sburlati, A., Adair, W. L., JR \& Robbins, P. H. W. (1986). The $S$. cerevisiae structural gene for chitin synthase is not required for chitin synthesis in vivo. Cell 46, 213-225.

Bush, D. A., Horisberger, M., Horman, I. \& Wursch, P. (1974). The wall structure of Schizosaccharomyces pombe. Journal of General Microbiology 81, 199-206.

DAvis, L. L. \& BarTnICKI-GarCIA, S. (1984). Chitosan synthesis by the tandem action of chitin synthetase and chitin deacetylase from Mucor rouxii. Biochemical Journal 23, 1065-1068.

Elorza, M. V., Murgui, A., Rico, H., Miragall, F. \& Sentandreu, R. (1987). Formation of a new cell wall by protoplasts of Candida albicans: effect of papulacandin B, tunicamycin and nikkomycin. Journal of General Microbiology 133, 2315-2325.

FaIRBaIRN, N. J. (1953). A modified anthrone reagent. Chemistry and Industry 72, 86

HoRISBERger, M. \& Rouvet-VAuthey, M. (1985). Cell wall architecture of the fission yeast Schizosaccharomyces pombe. Experientia 41, 748-750.

Horisberger, M., Vonlanthen, M. \& Rosset, J. (1978). Localization of $\alpha$-galactomannan and of wheat germ agglutinin receptors in Schizosaccharomyces pombe. Archives of Microbiology 119, 107-111.
Horton, D. \& Wolfrom, M. L. (1963). Polysaccharides. In Comprehensive Biochemistry, vol. 5, pp. 189-232. Edited by $M$ Florkin \& E. H. Stotz. Amsterdam: Elsevier.

HouwINK, A. L. \& KREGER, D. R. (1953). Observations on the cell wall of yeasts. An electron microscope and X-ray diffraction study. Antonie van Leeuwenhoek 19, 1-24.

JoHnson, A. R. (1971). An improved method of hexosamine determination. Analytical Biochemistry 44, 628-635.

JoHnson, B. F. (1965). Autoradiographic analysis of regional cell wall growth of yeasts: Schizosaccharomyces pombe. Experimental Cell Research 39, 613-624.

Krebs, K. G., Heusser, D. \& Wimmer, H. (1969). Spray reagents. In Thin-Layer Chromatography, pp. 854-908. Edited by E. Stahl. Berlin: Springer Verlag.

KREGER, D. R. (1954). Observations on cell walls of yeasts and some other fungi by X-ray diffraction and solubility tests. Biochimica et Biophysica Acta 13, 1-11.

MANNERS, D. J. \& MEYER, M. T. (1977). The molecular structure of some glucans from the cell walls of Schizosaccharomyces pombe. Carbohydrate Research 57, 189-203.

Mitchison, J. M. \& NurSe, P. (1985). Growth in cell length in the fission yeast Schizosaccharomyces pombe. Journal of Cell Science $\mathbf{7 5}$ 357-376.

Mol, P. C. \& Wessels, J. G. H. (1987). Linkages between glucosaminoglycan and glucan determine alkali-insolubility of the glucan in walls of Saccharomyces cerevisiae. FEMS Microbiology Letters 41, 95-99.

Molano, J., Bowers, B. \& Cabib, E. (1980). Distribution of chitin in the yeast cell wall. An ultrastructural and chemical study. Journal of Cell Biology 261, 15147-15152.

POOLE, R. K. \& LLOYD, D. (1973). Effect of 2-deoxy-D-glucose on growth and cell walls of Schizosaccharomyces pombe $972 \mathrm{~h}^{-}$. Archiv für Mikrobiologie 88, 257-272.

Sburlati, A. \& CabiB, E. (1986). Chitin synthetase 2, a presumed participant in septum formation in Saccharomyces cerevisiae. Journal of Biological Chemistry 261, 15147-15152.

ShIVely, J. E. \& CoNRAD, H. E. (1970). Stoichiometry of the nitrous acid deaminative cleavage of model aminosugar glycosides and glycosaminoglycuronans. Biochemistry 9, 33-43.

Sietsma, J. H. \& Wessels, J. G. H. (1979). Evidence for covalent linkages between chitin and $\beta$-glucan in a fungal wall. Journal of General Microbiology 114, 99-108.

SoMOGYI, M. (1945). An improved method for the estimation of reducing sugars. Journal of Biological Chemistry 153, 375-377.

SPIES, J. R. (1957). Colorometric procedures for amino acids. Methods in Enzymology 3, 467-477.

Stagg, M. C. \& Feather, M. S. (1973). The characterization of a chitin-associated D-glucan from the cell walls of Aspergillus niger. Biochimica et Biophysica Acta 320, 64-72.

Streiblova, E. (1981). Fission. In Yeast Cell Envelopes: Biochemistry, Biophysics and Ultrastructure, vol. II, pp. 79-92. Edited by W. N. Arnold, Boca Raton, Florida: CRC Press.

Surarit, R., Gopal, P. K. \& Shepherd, M. G. (1988). Evidence for a glycosidic linkage between chitin and glucan in the cell wall of Candida albicans. Journal of General Microbiology 134, 1723-1730.

Wessels, J. G. H., Sievsma, J. H. \& SonNenberg, A. S. M. (1983). Wall synthesis and assembly during hyphal morphogenesis in Schizophyllum commune. Journal General Microbiology 129, 1607-1616.

Wessels, J. G. H., Mol, P. C., Sietsma, J. H. \& Vermeulen, C. A (1989). Wall structure, wall growth and fungal cell morphogenesis. In Biochemistry of Cell Walls and Membranes in Fungi, pp. 81-95. Edited by P. J. Kuhn, A. P. J. Trinci, M. J. Jung, M. W. Goosey \& L. G. Copping. Berlin: Springer Verlag. 